E International

\title{
Shifting towards Low Carbon Mobility Systems
}

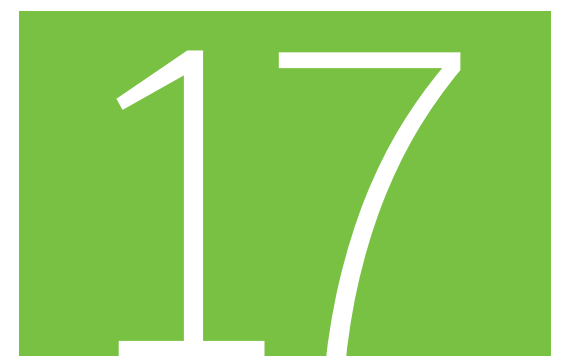

Discussion Paper 2015 17

Aimée Aguilar Jaber

International Transport Forum, Paris, France

Daniela Glocker

The Organisation for Economic

Co-operation and Development (OECD),

Paris, France 


\section{Shifting towards low carbon mobility systems}

Discussion Paper No. 2015-17

Aimée AGUILAR JABER,

International Transport Forum at the OECD, Paris

Daniela GLOCKER,

OECD, Paris

May 2015 


\section{THE INTERNATIONAL TRANSPORT FORUM}

The International Transport Forum at the OECD is an intergovernmental organisation with 54 member countries. It acts as a strategic think-tank, with the objective of helping shape the transport policy agenda on a global level and ensuring that it contributes to economic growth, environmental protection, social inclusion and the preservation of human life and well-being. The International Transport Forum organises an Annual Summit of ministers along with leading representatives from industry, civil society and academia.

The International Transport Forum was created under a Declaration issued by the Council of Ministers of the ECMT (European Conference of Ministers of Transport) at its Ministerial Session in May 2006 under the legal authority of the Protocol of the ECMT, signed in Brussels on 17 October 1953, and legal instruments of the OECD.

The Members of the Forum are: Albania, Armenia, Australia, Austria, Azerbaijan, Belarus, Belgium, Bosnia and Herzegovina, Bulgaria, Canada, Chile, China (People's Republic of), Croatia, Czech Republic, Denmark, Estonia, Finland, France, Former Yugoslav Republic of Macedonia, Georgia, Germany, Greece, Hungary, Iceland, India, Ireland, Italy, Japan, Korea, Latvia, Liechtenstein, Lithuania, Luxembourg, Malta, Mexico, Republic of Moldova, Montenegro, Netherlands, New Zealand, Norway, Poland, Portugal, Romania, Russian Federation, Serbia, Slovak Republic, Slovenia, Spain, Sweden, Switzerland, Turkey, Ukraine, United Kingdom and United States.

The International Transport Forum's Research Centre gathers statistics and conducts co-operative research programmes addressing all modes of transport. Its findings are widely disseminated and support policymaking in member countries as well as contributing to the Annual Summit.

\section{Discussion Papers}

The International Transport Forum's Discussion Paper Series makes economic research, commissioned or carried out at its Research Centre, available to researchers and practitioners. The aim is to contribute to the understanding of the transport sector and to provide inputs to transport policy design.

ITF Discussion Papers should not be reported as representing the official views of the ITF or of its member countries. The opinions expressed and arguments employed are those of the authors.

Discussion Papers describe preliminary results or research in progress by the author(s) and are published to stimulate discussion on a broad range of issues on which the ITF works. Comments on Discussion Papers are welcomed, and may be sent to: International Transport Forum/OECD, 2 rue André-Pascal, 75775 Paris Cedex 16, France.

For further information on the Discussion Papers and other JTRC activities, please email: itf.contact@oecd.org

The Discussion Papers can be downloaded from: www.internationaltransportforum.org/jtrc/DiscussionPapers/jtrcpapers.html

The International Transport Forum's website is at: www.internationaltransportforum.org

This document and any map included herein are without prejudice to the status of or sovereignty over any territory, to the delimitation of international frontiers and boundaries and to the name of any territory, city or area. 


\section{Acknowledgement}

This paper was developed jointly by the International Transport Forum and the Public Governance and Territorial Development of the OECD as a contribution to the 2015 OECD report for Ministers on Aligning Policies for the Transition to a Low-carbon Ecconomy with support from the OECD Environment Directorate. 



\section{Table of contents}

Introduction 7

Part 1. Long-term impact of transport and urban development Policies on co2 emissions: scenarios for urban Latin america, China and India.

Part 2. Institutional challenges for implementing sustainable urban transport strategies

Investment, planning and implementation of urban transport are often divorced from complementary urban development policies.

Governmental fragmentation complicates the alignment of low-carbon objectives

Absence of (physical, operational, fare) integration among multiplicity of transport policy actors weakens the competitiveness of low-carbon transport modes

Inconsistent policies within the urban transport sector hinder effective overall transport demand management.

Misalignment of fund allocation mechanisms with low carbon objectives limits financial viability of public transport and non-motorised modes.

Part 3. Successful approaches to better institutional coordination for advancing sustainable urban transport strategies

Forms of metropolitan governance arrangements can facilitate achievement of low-carbon objectives

National Frameworks can guide urban transport policy towards sustainable,

low carbon urban transport

Conclusion

Bibliography 



\section{Introduction}

Private motorised vehicles account today for $90 \%$ of total surface transport ${ }^{1} \mathrm{CO}_{2}$ emissions. Car fleets are growing rapidly in many cities in the developing world, where population and income growth will be concentrated in the coming decades. For example, whilst urban agglomerations with more than 500000 inhabitants in Latin America, India and China currently account for only about $9 \%$ of total global $\mathrm{CO}_{2}$ emissions from motorised passenger surface transport, this share is likely to grow to $20 \%$ in the next 40 years. This means that $40 \%$ of the total global growth in $\mathrm{CO}_{2}$ emissions related to surface passenger transport will be generated in these cities (ITF, 2015).

Shifting towards low-carbon mobility (reducing carbon emitted per unit of transport activity) will require integrated policies. Strategies focusing on accelerating penetration of less carbon intensive vehicle technologies are very important and are illustrated in the next section with a review of incentives to accelerate purchase of electric vehicles. But, policies that can avoid unnecessary transport activity ${ }^{2}$ and significantly shift activity to less carbon intensive modes while meeting mobility demand are also a key element to achieve stabilization of $\mathrm{CO}_{2}$ emissions. Despite the concentration of wealth-generating activities in urban centres leading to motorization rising first in cities, urban areas present particular characteristics that make it possible to achieve mobility that is less reliant on cars and motorcycles.

- Due to higher density of demand, the potential for relying on public mass transport to meet mobility needs is larger in cities than elsewhere.

- By shortening average distances travelled, higher densities can also make it more feasible for nonmotorised transport (such as cycling and walking) to play a relevant role in urban mobility.

- Congestion tends to limit the benefits of using private transport in urban centres as motorisation grows and road space becomes scarce.

Ex-post analysis of specific projects that involve mass transit investment and/or improvement of existing bus services, such as Metrobus in Mexico, Transmilenio in Colombia, and Trans-Jakarta in Indonesia have yielded evidence of the capacity of these projects to contribute to the reduction of the $\mathrm{CO}_{2}$ intensity of urban mobility by "inducing passengers to switch modes, to switch to larger units within modes, or through improved occupancy rates" (Hook, et al., 2010). However, achieving significant $\mathrm{CO}_{2}$ emission reductions at national and global scale through 'avoid and shift' strategies requires a wider alignment of policies and incentives across the various domains of urban planning. Fragmentation among local, regional, and national governments creates policy contradictions and misalignments that hinder the potential to reduce carbon emissions from urban mobility.

1 Road and rail modes.

2 Or more accurately reduce the mobility required for access to employment, goods and services. 
The present section of this report provides results obtained through modelling carried out for the Transport Outlook of the International Transport Forum (ITF) of the long-term $\mathrm{CO}_{2}$ mitigation potential of aligning policies towards public transport-oriented urbanisation in Latin America, China, and India (part 1). It will then review some of the major institutional challenges for achieving policy coordination and implementing sustainable urban transport strategies in urban centres (part 2). It also provides evidence from cities that have made significant progress in increasing institutional coordination for advancing sustainable urban transport strategies (part 3). 


\section{Part 1. Long-term impact of transport and urban development policies on CO2 emissions: scenarios for urban Latin America, China and India.}

Urban transport scenarios for Latin America, China and India were constructed with the aim of testing the long-run impact of alternative urban transport policy packages on $\mathrm{CO}_{2}$ emissions if they were to be adopted across the region. Four types of variables characterising the urban context were identified as most relevant to transport demand: land-use planning (density of development), investment in public transport, investment in road infrastructure, and fuel prices. The evolution of each variable between scenarios was adjusted to high and low bounds calibrated for each region on the basis of the range of city land use and transport development patterns that currently exist in that region. A description of the ITF urban transport model and scenarios modeled is provided in Box 1, and more detailed information on this work is available in the ITF Transport Outlook 2015.

Results from the three regions reveal the extent to which urban planning decisions and the alignment of policies towards private or public transport-oriented urbanisation translate into differences in the modal composition of urban mobility.

In a scenario where urban policies promote private transport use, and in particular car use, by permitting sprawl, letting public transport expansion lag behind population growth, heavily investing in urban road infrastructure expansion and maintaining low fuel prices, public transport accounts for only $11 \%$ of urban mobility in Latin America and India by 2050, and for 9\% in China (Figure 1).

By contrast, the alignment of policies that contain sprawl, set higher fuel prices, and prioritise the expansion of public transport infrastructure over urban road infrastructure can maintain current shares of public transport in Latin American and Indian cities through 2050. In China, the same policy alignment, combined with the extension of car ownership restrictions to all medium and large cities, can significantly slow the shift from public to private mobility.

The set of policies modelled in the private-oriented urbanisation scenarios increase mobility levels relative to baseline mobility in all three cases (Figure 2 left-hand panel). An important driver is the increase in travel per private vehicle as a result of low oil prices. The additional mobility in all three cases is more carbon intensive and generates significantly higher $\mathrm{CO}_{2}$ emissions than transport in the respective baseline scenarios. Under this policy framework $\mathrm{CO}_{2}$ emissions related to urban transport in Latin America, China and India grow more than in the baseline scenarios by 35\%, 19\%, and $47 \%$ respectively (Figure 2 right-hand panel).

The shift to public transport-oriented urbanisation has certain mobility costs, as significant public transport expansion with major extensions of mass transit systems needs to be carried out before public transport systems can absorb the mobility displaced by higher costs for private mobility. For Latin America and China, mobility under the public transport-oriented scenario with low road infrastructure expansion would catch up with baseline levels of mobility towards the end of the period, with a gap of only around $5 \%$ of growth in passenger-kilometres by 2050 . In the case of India, despite the lower initial private mobility shares, the relatively poor public transport infrastructure has more difficulty in 
expanding sufficiently to meet growing mobility needs. Therefore, mobility in the public transportoriented urbanisation scenarios with low roads remains below the levels delivered under baseline and private transport-oriented urbanisation policy frameworks in India.

Overall, alignment of policies toward public transport-oriented urbanisation reduces the carbon intensity of urban mobility. This cuts transport related $\mathrm{CO}_{2}$ emission growth by $31 \%$ in urban Latin America, 26\% in China and 37\% in India.

\section{Box 1. ITF Urban transport model and scenarios for Latin America, China and India}

The ITF urban transport model simulates the evolution of the main variables of the urban environment that are relevant to transport demand in agglomerations under different policy scenarios (land-use, public transport, road infrastructure and fuel prices). The model derives levels of transport activity and modal shares that would result under each scenario. The agglomerations included have 500000 or more inhabitants. The model adopts assumptions on load factors, fuel economy and $\mathrm{CO}_{2}$ emission factors from the MoMo mobility model of the International Energy Agency. Emissions of local air pollutants and the health impacts that would result from each scenario are calculated by the International Council for Clean Transportation (ICCT).

The model framework is built on the projections of urban agglomeration of the UN Urbanization Prospects, 2014 Revision. We extend their projections from 2035 to 2050 using UN methodology described in United Nations (2011), comparing the results to existing literature where possible. Urban GDP per capita scenarios are calculated from national GDP projections provided by the ENV-Growth model of the OECD Environmental Directorate.

The model is composed of individual regional modules. This allows flexibility to use the available urban transport data of each region and set relations between variables according to the specific trends found in each of them. Three modules have been constructred to date: Latin America, China, and India.

\section{Modeled Scenarios}

Baseline scenarios for all variables are constructed on the assumption that current trends in each of the contexts will continue in the future.

For China, two additional assumptions with respect to future evolution of car ownership restrictionswere drawn. First, the seven cities $^{3}$ that had a car ownership restriction in 2010 are expected to maintain their policy in place over the next 40 years. A constant number of licences issued yearly, defined according to official announcements for each city was assumed. Second, a city will impose a restriction if it reaches at least 2.5 million inhabitants coupled with at least the ratio of cars over road area that the seven cities with car ownership restrictions had in $2010^{4}$.

Two divergent policy pathways are modelled:

1) A private transport-oriented urbanisation scenario is constructed by applying policy trends that intensify the shift to private mode use. These are high sprawl, low expansion of public transport, and low fuel prices. This scenario is combined with a scenario of rapid expansion of road infrastructure (high roads).

In the case of China, no expansion of car ownership restriction policies is assumed. Therefore only cities that already had a car ownership restriction by 2010 have one until the end of the projected period.

2) A public transport-oriented urbanisation scenario was built by assuming alignment of policy trends that increase the role of public transport in urban mobility. This scenario is the combination of low sprawl, high public transport expansion, and high fuel prices. The policy pathway is modelled in a context of urban road infrastructure lagging behind urban population growth (low roads).

This scenario also assumes a stronger willingness to reduce car ownership through expansion of stricter car ownership restrictions in China. Assumptions on expansion of car ownership restrictions are the same than in the Baseline case. However, the number of licences issued is now adjusted to population growth to counter-act the plateauing of population in Chinese cities.

3 Beijing, Guangzhou, Guiyang, Hangzhou, Shanghai, Shijiazhuang and Tianjin

4 The number of licences issued each year is defined applying a constant coefficient relative to the car-road area ratio, extracted from the econometrics analysis of permits and congestion on the sample of seven cities. 
Figure 1. Modal shares under different policy scenarios in urban agglomerations above 500000 population, 2010 and 2050

Passenger-kilometres

\section{Latin American Cities}

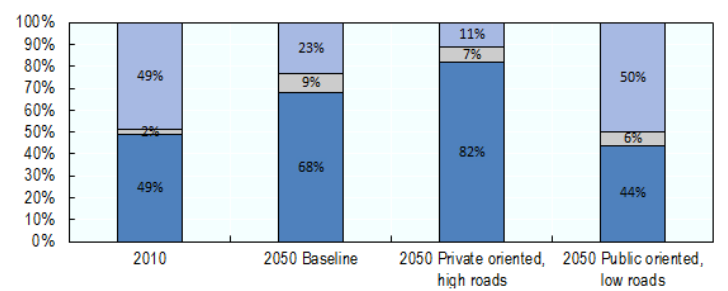

Chinese Cities

Indian Cities
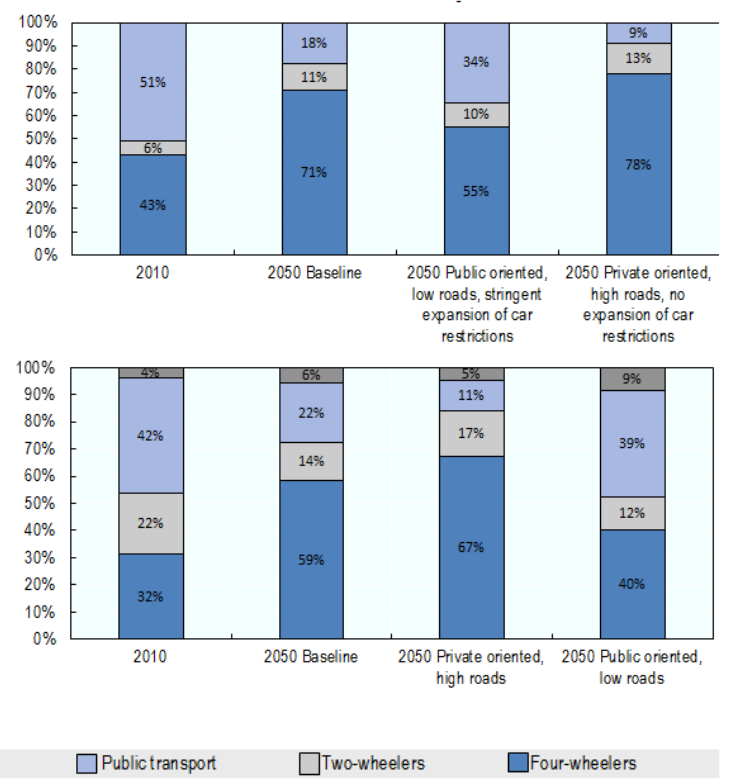

Note: Two-wheelers are powered two-wheeled vehicles, motorcycles and scooters, Four-wheelers are defined as passenger cars and light-trucks.

Figure 2. 2010-2050 growth in mobility and related CO2 emissions in alternative scenarios for Latin American, Chinese and Indian cities Index $2010=100$

Growth in passenger kilometres



- Private transport oriented, low roads

-Baseline
Growth in $\mathrm{CO}_{2}$ emissions

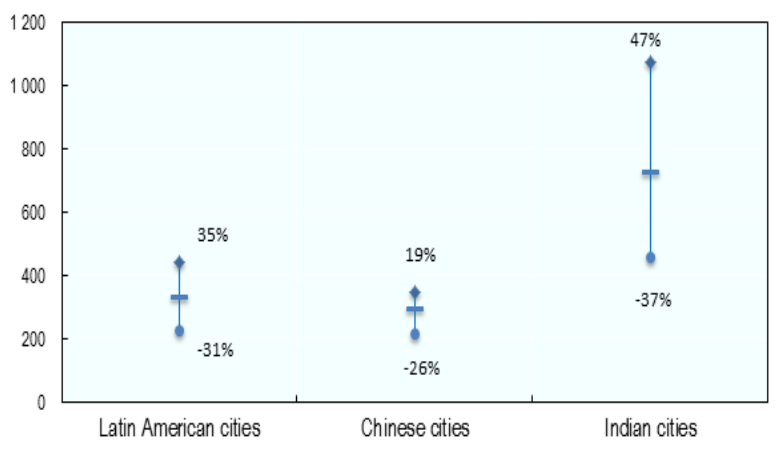

- Public transport oriented, high roads 


\title{
Part 2. Institutional challenges for implementing sustainable urban transport strategies
}

\begin{abstract}
Alignment of policies towards low carbon mobility goals is often impeded by policy contradictions that result from government fragmentation between: a) institutions in charge of transport and other complementary urban policies (e.g. land-use); b) authorities from neighbouring jurisdictions that are part of a same urban agglomeration; c) entities in charge of the different modes of transport; and d) different levels of government.
\end{abstract}

This section will illustrate the specific consequences of such contradictions.

\section{Investment, planning and implementation of urban transport are often divorced from complementary urban development policies}

Because "transport and housing are imbedded goods" (Cervero, 2011), and decisions on one are highly dependent on the other, integration of transport and land-use planning is particularly important for low-carbon urban mobility. Transit oriented development (TOD) has been recognised as an important strategy for reducing carbon intensity of urban mobility through better coordination of land-use and transport development with the objective of avoiding unnecessary transport activity and shifting activity to less carbon intensive modes.

TOD proposes to build mass transit corridors that serve as the main transportation axes of cities but also to build high density development along these corridors. High densities increase the scope for demand of the mass transit systems, making it easier for governments to provide the service with less economic burden and/or making it easier to attract private investors. TOD also allows building large areas of housing that are well-served by public transport service. TOD also proposes fostering mixed land-use that tends to reduce average distance of trips and facilitates non-motorised transport. By increasing the financial viability of public and non-motorised transports as well as improving conditions for their use, TOD attains higher participation of these-less carbon intensive-modes in total urban mobility.

Despite the growing endorsement of TOD principles among policy makers, in the vast majority of cities land-use and transport planning remains the responsibility of separate authorities with limited or no coordination between them. Moreover, misalignment of objectives across different levels of governments increases complexity for integrated urban development planning.

\section{National frameworks may promote urban sprawl and thus increase the reliance on private modes and higher distance travel to meet urban mobility needs}

In several countries fiscal incentives promote urban sprawl by favouring single-family, owneroccupied housing over multi-family or rental housing. In the United States, for example, property taxes rates are often higher for multi-family dwellings and tax breaks for home ownership are in place. Furthermore, in most of the OECD area, property taxes are imposed mainly on buildings and other 
improvements rather than on land values. Those who are holding good sites for infill but do not use them are taxed very little, and it is often more profitable for new developments to take place on greenfield sites (OECD 2014a). In China, no property taxes are in place, but cities' revenues depend heavily on land related income, such as land leases, land auctions and land development rights. Moreover, cities have incentives to make large tracks available for industrial development in order to attract investment, while restricting the supply of land for the residential and service sectors (OECD 2014a). In many countries, for example in Mexico or Chile, urban housing authorities have also adopted as common practice the provision of low-income housing on city peripheries, where land is cheaper, but access to public transport is poor and financially unsustainable ( OECD 2015b, OECD, 2013c).

\section{Transport improvements in the absence of land-use planning will not meet objectives of re- shaping urban development}

In a similar fashion, the potential for mass transit investments to reshape urban development and travel behaviour has been limited in most cases by a lack of integration of land-use policy into urban transport project planning. For example, BRT systems in Bogotá, Colombia and Ahmedabad, Indiaamong other examples- were implemented as isolated mobility investments and bus-corridor construction has not been accompanied by complementary policies to shape urban growth in a TOD manner. In Bogotá, limited planning for the optimal location of station areas ${ }^{5}$ for the Transmilenio BRT system and the lack of incentives for private property-owners to redevelop land around corridors have hindered its effects on urban development. In Ahmedabad, land-use planning around stations has also been absent in the planning process of the Janmarg BRT system. This has resulted in low pedestrian accessibility to BRT stops and has limited land-use change around stations (Cervero and Dai, 2014).

\section{Governmental fragmentation complicates the alignment of low-carbon objectives}

In addition to the lack of integration between transport and land-use planning, the institutions governing land use and transport decisions for planning infrastructure may not be designed at the most effective functional scale. In many countries land-use planning lies under the authority of spatial planning units that are usually defined by the smallest administrative unit of government rather than functional criteria. ${ }^{6}$ The lack of a coherent spatial plan across administrative units within an urban agglomeration, as well as the disconnect between spatial planning and closely linked policy issues such as transport, which are often controlled by higher levels of government, can also run counter to low carbon objectives. In Mexico for example, the municipalities are responsible for urban planning and development whereas the state governments are in charge of mobility and transport policy, transport infrastructure and operation of public transport. In the metropolitan area of Puebla-Tlaxcala limited coordination between levels of government and the lack of integration between transport and urban development have contributed to the suboptimal siting of some BRT routes (OECD 2013b). To guide a more integrated approach to land use and transport planning, many urban agglomerations have opted to create metropolitan governance bodies (Ahrend et al, 2014; OECD 2015a). This is addressed in more detail in part 3.

5 For cost reducing reasons, stations were for example located in the medians of busy roadways, often with poor pedestrian access and in economically depressed and marginalised urban areas with minimal development potential.

6 Urban agglomerations comprise several municipalities, that each usually has the power to regulate land use through building and zoning codes (OECD, 2015a). 


\section{Absence of (physical, operational, fare) integration among multiplicity of transport policy actors weakens the competitiveness of low-carbon transport modes}

An important requirement for public transport to be competitive and attract users is to develop well integrated systems. The term "integrated" refers to systems where all aspects of the public transport provision are coordinated with each other as well as with other existing modes. Integration needs to be:

- Physical, allowing minimizing transfer costs (monetary, time, safety, etc.) between segments of a same mode as well as between modes;

- Operational, which includes optimised routing and synchronised timetables between different lines and modes of transport; and

- Fare integration, which means having a universal fare scheme with tickets that are valid across different modes of public transport.

The successful integration of a public transport system is complicated by the increasing number of municipalities that make up urban agglomerations and the fact that the jurisdiction of transport authorities tends to correspond to administrative boundaries rather than to functional ones ${ }^{7}$. In various metropolitan areas, the transport system has not kept pace with the evolving urban pattern (e.g. suburb-to suburb traffic) and remains in a predominantly radial structure (e.g. core city to suburb traffic).

However, in some places not even city-to-suburbs traffic is adequately served. In Chicago, for example, approximately $36 \%$ of its population works outside the city, and $46 \%$ of workers in the city of Chicago live in the suburbs. Yet, the division of the public transport system into urban (Chicago Transit Authority, CTA) and sub-urban (Pace and Metra) authorities means that CTA bus services typically end abruptly at the city limits where Pace services begin, and none of Metra's downtown commuter rail connects directly to the CTA rail network (Merk, 2014).

Adequate physical, operational and tariff integration of BRT systems in cities remains one of the most important challenges. In most developing country cities, coordination of the BRT network across neighbouring municipalities has been difficult in the absence of metropolitan level authorities. Integration of BRT systems into a wider transport network has also been difficult under high levels of fragmentation between authorities that oversee different types of public transport services. In places like Kunming, Porto Alegre, Recife, Taipei, Quito, and Jakarta, the authorities have failed to coordinate fare collection technologies and/or physical integration even among BRT corridors operated by different companies. In Jakarta, passengers often buy a ticket every time they transfer BRT corridors to complete their journeys (Hidalgo, 2010).

In many OECD Metropolitan areas, there is a need to reform the fare system to remove the inconveniences caused by different payment schemes and the lack of transfer discount service, thereby improving public transport's competitiveness in terms of time and cost. Non-harmonised fare structures

7 The OECD, in collaboration with the EU, has constructed a new definition of cities that is comparable across countries and corresponds to their functional economic area rather than administrative boundaries. The Functional Urban Area (FUA) methodology uses information on density and commuting patterns in order to identify boundaries that approximate the city's functional labour market (OECD (2012), Redefining "Urban": A New Way of Measuring Metropolitan Areas, OECD Publishing). has achieved agreement between transport providers and between municipal level authorities. Improvements could still be achieved with the creation of a metropolitan level authority 
can for example be found in Chicago (US), Marseille (France), Athens-Attica (Greece), Puebla-Tlaxcala (Mexico) or Daejeon (Korea) to mention but a few (see e.g. OECD, 2015a).

The absence of an integrated public transport system contributes to significant urban and environmental problems, by reinforcing car dependence and congestion. Weaknesses in the public transport system also reduce resident mobility and limit the perimeter of their potential job markets, thus exacerbating inequalities in terms of access to employment within the metropolitan area.

In Marseille, around $77 \%$ of the population living in peri-urban areas has no access to public transport, $14 \%$ of the population has limited access and only $2 \%$ has high access. Only $10 \%$ of travel between Aix and Marseille is done by public transport. Private cars account for $90 \%$ of trips within the metropolitan area. Road traffic increased by $10 \%$ between 1997 and 2009 and the roadways leading to the main urban cores of the metropolitan area are increasingly congested (OECD, 2013a). As a result, in 2013 Marseille was the most congested city in France and the seventh most congested city in Europe (out of 60 major cities) (TomTom Traffic Index 2014)

In Puebla-Tlaxcala, the public transport fleet consists almost exclusively of low-capacity vehicles such as microbuses, minibuses and taxis, further contributing to congestion and impeding the development of an efficient transport network. ${ }^{9}$ Approximately 6000 public transport vehicles circulate in the Puebla-Tlaxcala metropolitan zone, with multiple operators covering some of the same routes (284 routes in total), especially in the city centre. The inefficiency of the current transport system often forces workers to ride two or three different buses to get to work. The current transport system also contributes to social segregation. Many workers - especially the lower income categories - live in farflung communities in the periphery and spend more than two or three hours in commuting every day (OECD, 2013b).

\section{Inconsistent policies within the urban transport sector hinder effective overall transport demand management.}

In the bigger picture, urban transport strategies should align policies across modes with low carbon mobility objectives. Pricing structure and road space prioritization should therefore "discourage unnecessary private vehicle use and promote more effective, healthy and environmental-friendly modes of transport, in general being public transport and non-motorised transport"(Broaddus, et al, 2009). However, achieving coordination between the multiple entities responsible for regulating different modes and related infrastructures is complicated and can be a long process.

Misalignment of pricing frameworks often impedes efforts to improve competitiveness of transport modes that reduce carbon-intensity. For example, although the regional 2040 Growth Concept in Portland adopted in 1995 aimed at tripling the combined modal shares of public transport, walking and cycling by 2040, some parallel policies are stimulating car use. Such policies include a gas tax that is relatively low from an international perspective and the lack of congestion charges or parking fees in most areas (Oregon Metro, 2014).

In Latin America, national policies have in general maintained low costs for car use by subsidizing fuel and stimulating the financial sector to give advantageous credit facilities for automobile acquisition. At the local level, parking policies have often been non-existent in many areas of Latin American cities, and a recurrent strategy has been to transfer on-road parking to parking lots without restricting parking space supply. Moreover, parking tariffs tend to be low and in some cases maximum tariffs are set by 
local authorities. In cities like Monterrey, Santiago, Porto Alegre, and Rio de Janeiro, a public transport ticket is significantly more expensive than an hour of parking, in average (BID, 2013).

Misalignment of pricing frameworks with low carbon policy objectives also limits the opportunities to cross subsidise lower carbon intensity modes with revenues collected from higher carbon intensity modes. Cross subsidising has proven a good way to increase acceptability of transport demand management policies and increase funding availability and certainty for public transport and nonmotorised infrastructure (see part 3).

\section{Misalignment of fund allocation mechanisms with low carbon objectives limits financial viability of public transport and non-motorised modes}

Improving and expanding low carbon transport modes can be challenging due to uncertain long term financial stability. In order to provide a sustainable and competitive public transport network, constant investments in infrastructure and operation are needed, and in most cases subsidies are required to maintain quality and affordability. The lack of a framework that can channel available funding towards transport projects that promote low-carbon modes importantly hinders the capacity to improve and expand their capacity.

In some countries, such as Indonesia and Mexico, the institutional configuration has tended to make cities highly dependent on national funds to finance infrastructure, which may further limit available funding as it is subject to economic shocks. In Mexico, an additional problem results from the fact that national funds, which make up the largest share of available funding for urban mobility are not established in a federal regulation. Rather, they come from a source of the federal budget that is subject to yearly negotiations. Therefore, there is little certainty about the size of funds, their allocation to different state and municipal entities (ITDP, 2014). In other countries, cities have developed a greater capacity to generate local funds but have difficulties obtaining national government's approval to use certain sources of revenue. This is the case for cities in Denmark with respect to revenues from congestion charges, because they are considered new taxes (OECD 2013d).

Limited funding sources often generate underinvestment in transport systems and in particular in public transport facilities. Several large urban areas throughout Europe and North America have relatively mature public transport networks whose operation and upkeep require significant revenue. In the Chicago region, which has one of the largest rail and bus networks in the United States, public transport has suffered from major underinvestment in maintenance and upkeep. A declining customer base, as well as missing opportunities to cross subsidise public transport, further limits revenues. Thus, the region faces a considerable backlog in maintenance and infrastructure spending that compromises existing and future services. Financial sustainability has been elusive as well, and the current system based largely on fare and sales tax revenue will struggle to keep up with growing expenses (ITF, 2013).

A second part of the problem is the lack of coordination of investment that comes from different sources (within multiple national funds or between these and local funds), and the link between such investment decisions and low-carbon urban transport strategies. In the case of Mexico there has been a lack of coordination in the projects implemented with the multiple (13) funds that can be used to finance urban mobility. Moreover, the lack of a mechanism to link federal grants to local project implementation according to sustainable urban mobility objectives has resulted in a very high share of mobility-related funds being spent on urban roads. In 2013, 74\% of federal funds invested in urban mobility in 59 metropolitan areas were spent on road infrastructure (ITDP, 2014). 


\section{Part 3. Successful approaches to better institutional coordination for advancing sustainable urban transport strategies.}

Close coordination and the (horizontal and vertical) alignment of objectives across governments as well as the evaluation of the fund allocation sets the conditions for efficient public transport investment in order to provide efficient spending and thus avoid duplicate and counter-objective (see OECD, (2013e) for the principles of effective public investment). This section will focus on examples of successful policy coordination that have led to reduced carbon intensity of urban mobility.

\section{Forms of metropolitan governance arrangements can facilitate achievement of low-carbon objectives}

Urban agglomerations comprise a number of municipalities and thus municipal actors dealing with transport. Thus, providing a well-functioning transport network extending beyond administrative boundaries and covering all of the urban area becomes more challenging. However, inter-jurisdictional competition, fiscal frameworks that promote certain tax or spending practices or regulatory and other impediments may obstruct collaboration (see e.g. OECD2014a, OECD 2013c, and OECD 2013e). There is no "one size fits all" strategy for overcoming these difficulties; rather, different configurations of coordination have proven successful in different contexts.

In some areas, the creation of transport coordinating bodies at the metropolitan scale has proven useful to develop more coherent transport policies in a given metropolitan region made up of various local authorities and also to improve coordination between the public and private stakeholders involved in the provision of transport. A wide range of institutional configurations for the creation of transport coordinating bodies has been put into place:

Meetings of stakeholders are the simplest form of informal coordination, providing a forum for the exchange of information. This form of coordination requires limited budget and human resources, and is thus often (but not only) applied in developing countries. However, as the transport planning becomes more complex, building consensus through this relatively informal institutional configuration becomes more difficult. For example, in Indonesia, it took five years to reach consensus among agencies in order to advance a presidential decree on spatial planning of the Jakarta Metropolitan Area and regions that surround it (Kawaguchi, et al., 2013).

At the other side of the spectrum, transport coordination could also be managed through the formation of a more formal coordinating body, which might have its own funding resources and need not depend on financing from participating organizations. Examples of this configuration are the Consorcio Regional de Transportes de Madrid, which is an autonomous body of the Regional Government of Madrid (CRTM); Transport for London (TfL), which is a functional body of the Greater London Authority that reports directly to the Mayor of London; and the Syndicat des transports d'île de France (STIF) which is the transport coordinating body for the Paris metropolitan region (Île-de-France) and whose governing board is composed of elected representatives of the Regional and Departmental Councils, the Council of Paris, the regional chamber of commerce and a local grouping of municipalities 
(ITF, 2013). Coordinating bodies such as these are not only responsible for planning, organising, and financing public transport services, but have evolved to include a larger scope of urban transport e.g. management of streets, parking, bicycle infrastructure and facilities, public space and access to public transport.

Consolidation of independent authorities with a metropolitan scale and multi-modal planning and management capacity has demonstrated the most significant progress towards the development of an integrated transport planning and delivery framework that fosters less carbon intensive urban mobility.

In a few cases such as the Land Transport Authority (LTA) in Singapore, further steps have been taken. Not only transport planning, but also its coordination with land-use planning is coordinated by such an institution. This subsection will highlight some examples where this type of coordinating body has solved some of the most important governmental coordination problems that hinder progress towards low carbon urban mobility.

\section{Transport for London - United Kingdom}

In the United Kingdom, Transport for London (TfL) is a statutory body created by the Greater London Authority (GLA) Act 1999. This Act gives the Mayor of London a general duty to develop and apply policies to promote and encourage safe, integrated, efficient and economic transport facilities and services to, from and within London. TfL is directed by a board of between 8 and 17 members who are appointed by the Mayor of London and decisions are made by majority vote. TfL is in charge of the operation of public transport, highway construction and management including congestion charging and vehicle licensing. In order to align the development of an increasing population with their objective for more sustainable low-carbon transport, TfL investments range from introducing cleaner busses to encouraging alternatives to motorised travel like cycling and walking through improvements to the urban environment. These investments, as well as improving the efficiency of their operations, resulted in a decline of carbon emission. Thus, in 2012/2013, TfL already reached their target set for 2017/18: To reduce the normalised $\mathrm{CO}_{2}$ emissions (measured in grams of $\mathrm{CO}_{2}$ per passenger $\mathrm{km}$ ) from the main public transport services by $20 \%$ against a 2005/06 baseline (TfL, 2013). The capacity for continuous investments and improvements are financially ensured by six main sources: income from fares and the congestion charging scheme, central government funding, a proportion of London business rates, prudential borrowing, commercial development of their estate, including advertising and property rental, and development and third-party funding for specific projects (TfL, 2014). London can rely on a large and growing customer base that allows them to keep up with the costs and to deploy new services. This customer base is somewhat guaranteed via demographic dynamics, active land-use planning policies and other measures such as the London congestion charge that ensure a sustained public transport market (ITF, 2013).

\section{Metropolitan Planning Organisation (MPO) - United States}

In the United States, urban areas with more than 50000 residents must have a designated metropolitan planning organisation (MPO) in order to qualify for federal transport funding. In order to obtain federal funding, MPOs are required to produce long-term transport plans based on a comprehensive analysis of demographic, travel, and employment trends for their regions and propose a series of transport improvements to meet projected needs. Each decision on major investments planned for the region must be evaluated against a set of alternatives in order to ensure that the most cost effective solutions are chosen. The long term plans are then translated into rolling five-year Transport Improvement Programmes (TIP), which list all projects to be funded in the MPO's jurisdiction over the next five years, and identify the sources of funding that have been allocated to each. This certain (long- 
term) funding stream relieves the financial strain on metropolitan authorities in their quest to meet increasing needs for metropolitan-wide mobility and encourages co-ordinated decision (OECD, 2015a).

The Chicago region (north-eastern Illinois counties of Cook, DuPage, Kane, Kendall, Lake, McHenry, and Will), for example, created the Chicago Metropolitan Agency for Planning (CMAP) in 2005. CMAP's board of directors and voting rules reflect the regional consensus that led to the creation of CMAP, featuring balanced representation from across the member counties. ${ }^{10}$ CMAP developed and now guides implementation of the GO TO 2040 comprehensive regional plan that seeks to maintain existing infrastructure of all types and gain operational efficiencies from it, make additional investments in transit and freight, use innovative and sustainable finance and system management ideas, link transportation investments with housing and land uses. In order to tackle the financial constraints for transport investments (see part 2), CMAP proposed implementing alternative funding and revenue sources such as increasing the state motor fuel tax, congestion charging and employing variable parking pricing. While the first two require a state or federal legislation ${ }^{11}$, respectively, the variable parking pricing could be implemented immediately by local authorities.

\section{Land Transport Authority (LTA) - Singapore}

In Singapore, the Land Transport Authority (LTA) is a statuary board under the Ministry of Transport established in 1995 as a result of a merger of four government agencies - the Registry of Vehicles, the Road Transport Division of Public Works Department, the Land Division Ministry of Communications and the Mass Rapid Transit Corporation. A higher degree of integration was achieved by removing administrative boundaries between private and public, and between the various modes of transport. The LTA is directed by an appointed board of directors comprising 15 representatives of business, academia, the professions, labour and community organisations. It is responsible for planning, operating, and maintaining land transport infrastructure and systems, including road safety, vehicle licensing and electronic road pricing. In order to reduce carbon emission, LTA constantly improves and expands its current public transport network complementing it with parking policies and electronic road pricing, resulting in a shift from private to public transport over the last years. Thus, in $201263 \%$ of trips during morning and evening peak times were on public transport, compared to 59\% in 2008. To increase this number even further, LTA aims for further improvements in order to provide a transport system that is highly accessible and competitive. By $2030,80 \%$ of households should be within a 10 minute walk from a train station, $85 \%$ of public transport journey (less than $20 \mathrm{~km}$ ) can be completed within 60minutes and that $75 \%$ of all journeys in peak hours are undertaken on public transport (LTA, 2013). The investments of the LTA towards an even more sustainable transport system mainly stems from government grants and operating income like management fees from the Government (taxes, fees and charges relating to land transport services) (LTA, 2014).

10. The board is composed of 15 members: 5 members from the City of Chicago, appointed by the Mayor of Chicago; 5 from suburban Cook County, appointed by county mayors in conjunction with the President of the County Board; and 5 members representing the collar counties cooperatively appointed by the counties' mayors and chief elected county officials. The board is chaired by a mayor (currently the mayor of Palos Hills). Approximately half of the board members are mayors, several are former elected officials, and the rest come from the business and civic community. Resolutions require 12 out of 15 votes to pass.

11. The CMAP timeline proposes the implementation of an increase in motor fuel tax in 2016 (legislation in 2015), and the legislation and implementation of congestion pricing by 2020 . 


\section{Rhein-Main-Verkerhsverbund (RMV) - Germany}

In Germany, every large urban agglomeration is covered by a transport authority. Such transport authorities usually bring together all local governments located in the metropolitan area as well as the corresponding federal states. They manage public transport provision across different modes of transport, provide strategic planning and coordinate pricing schemes for tickets that are valid across different modes of transport and different service providers. Typically, the sectorial authorities cover at least the full extent of the metropolitan area, but in some cases they reach significantly beyond their borders. In the Frankfurt metropolitan area, the Rhein-Main Transport Association (Rhein-Main Verkehrsverbund, RMV), brings together three levels of government: 15 counties, 11 cities, and the federal state of Hesse. All key decisions on policy and strategy are taken by the Supervisory Board of RMV GmbH that agrees on the range of services like offer and the fares system. Its members are delegates of the shareholders with each having one vote in order to adequately represent the different ideas and needs of the individual regions in the RMV network area. The RMV already has a well-integrated transport network, and in order to further encourage public transport usage, it continues to invest in improving accessibility, travel time and integration of transport modes. Between 2009 and 2013, the number of passenger trips on public transport increased from 660 million to 708 million. To complement low carbon emissions, the RMV additionally invests in cleaner trains and busses; thus, in 2011 hybrid busses were introduced to the transport network. The RMV is financed through fare revenues, federal funding transferred via the state governments and municipal funds (OECD, 2015a; RMV, 2014).

\section{Syndicat des transports d'Île-de-France (STIF) - France}

Organising transport authorities ( known as GARTs in French) have been created in France since 1980 with the aim of promoting urban transport alternatives to private cars (GART, 2014). The STIF is the organising transport authority for the Île-de-France and it is integrated by the Region of Île-deFrance, the departments that constitute the region, and the city of Paris (CEPAL, 2009).

The institutional setting of STIF is similar to other metropolitan areas of France but it has had more success than most other GARTs in achieving institutional coordination to advance low carbon mobility goals. For example, between 2001 and 2010 total public transport trips in the Île-de-France region rose $21 \%$, while car trips only grew by $0.6 \%$ (STIF, 2012).

The STIF concentrates an important range of attributes and responsibilities in transport planning. "It defines general operational and service level targets, sets fares and negotiates performance-based contracts with public service providers" (ITF, 2012). The STIF is also responsible for negotiating a contract with the national government (Contrat de Project Etat-Region or CPER) in which they agree upon a program for capital investment and they set funding responsibilities between national and Regional governments (ITF,2012).

STIF also develops an Urban Mobility Plan (PDU for its name in French) that includes, land-use and transport plans that guide all subordinate levels of government. The PDU includes precise objectives that should be met in order to contribute to the national $\mathrm{CO}_{2}$ emission mitigation target (20\% reduction by 2020$)^{12}$ and establishes a program of actions that will help attain such objectives. Only projects included in this list are subject to financing. This program of actions is subject to opinions from regional, general and municipal councils, transport users, experts, and environmental associations (STIF approves the plan after one month of public consultation). This framework has been important in fostering

12 Currently, these objectives are to have a $20 \%$ increase in public transport trips, a $10 \%$ increase in walking and cycling trips and a $2 \%$ reduction of car and motorcycle trips (STIF, 2014). 
consensus over future plans among all actors and has also facilitated public support. It has been important in giving coherence to the multiplicity of projects implemented by different authorities (since only those that are coherent with the plan can be financed) (CEPAL, 2009).

Having revenue from the "Versement Transport" tax has been important in enabling the STIF to extend and maintain the public transport network and non-motorised transport facilities in the Ile-deFrance (see next section for more information on this tax scheme). A significant bicycle sharing network has been financed to a great extent through advertising spaces in complement to user charges.

\section{Urban Transport Planning Authority Curitiba (URBS) - Brazil}

Curitiba's bus rapid transit system (BRT) is widely known as an example of a pragmatic, integrated, cost-effective, and efficient transport system. The city's success results from close cooperation between its Urban Transport Planning Authority (URBS), responsible for transport, and the urban development authority (IPUCC), which is in charge of land use planning. From its start in 1974, the Curitiba BRT was notable for its careful alignment with the 1965 Curitiba Master Plan, which focused the city's growth along major corridors through land use and zoning regulations. Building on this core concept, the Curitiba BRT has continually improved efficiency and expanded access. The integration of feeder and inter-district buses, with transfer stations and a single fare, created the Integrated Transport Network (RIT), considerably improving the systems coverage and utility. Today RIT covers 14 of the 26 cities of the metropolitan area (URBS, 2010). RIT was conceived around structural axles that provide the backbone of a transit-oriented development (TOD) initiative through relatively low-cost and high-impact interventions (ITDP, 2013; Demery, 2004). Despite a high rate of car ownership compared to the rest of Brazil, the BRT service, combined with parking policies resulted in fewer automobile trips per year and ambient air pollution is one of the lowest in Brazil (Lindau et al, 2010).

URBS is responsible for the planning, management, operation and control of the transportation system in Curitiba. It defines routes, capacity and schedules; regulates and controls the bus system; and collects all fares. Bus operations are contracted to private sector operators. Fare revenues are pooled and paid to the contracted operators on the basis of the services provided. The complete RIT system, with its range of buses and integrated flat passenger fare, is reported to operate without subsidy (Lindau et al, 2010).

\section{National Frameworks can guide urban transport policy towards sustainable, low carbon urban transport}

Despite a general historical trend for urban transport responsibilities to be assigned to local governments (especially for public and non-motorized modes), growing shares of population concentrated in urban centres have naturally increased the role of national governments in urban mobility. National government support in the guidance of urban transport policy and funding of urban transport projects has helped in many places to foster a faster, more homogeneous and wide spread improvement of mobility in the whole of urban centres of countries.

In places like India, France, Colombia and Brazil, the development of an explicit national policy for sustainable urban transport has helped to establish goals, guidelines, and standards for urban mobility to promote use of public and non-motorised transport (GIZ and EMBARQ, 2013). Development of a national level policy has also achieved prioritization of national funds for urban transport, which has increased the available budget for construction and improvement of public transport and non-motorized transport. In the case of Mexico, the development of a national urban transport policy is a recent and ongoing process that started with the newly formed Ministry of Rural, Territorial, and Urban Development (SEDATU) in 2013. Having placed urban transport at the national governmental level has 
driven discussions on the expansion of the available federal funds for sustainable urban transport strategies. For instance, a new programme aimed at the development of planning tools that can help align existing funds destined to mobility and increase modal shift towards public and non-motorized transport (Programa de Impulso a la Movilidad Urbana Sustentable) has recently been included in the list of programmes considered for funding in the expenditure plan of the Finance Ministry (Plan de Egresos de la Federación) (SEDATU, 2014).

\section{National urban transport funds can increase the coordination between urban transport and land use planning}

Linking national urban transport funds to integrated urban planning has proven useful to increase coordination of urban transport and land-use planning. In India, this has been facilitated by national funds made available for urban transport projects as part of a larger urban development project led and funded by the Ministry of Urban Development, the Jawaharlal Nehru National Urban Renewal Mission (JNNURM). In order to be eligible for funding under the JNNURM projects have to be part of a comprehensive city development plan (CDM), (Government of India, 2011). In the case of the USA's New Starts Program, project sponsor agencies are required by the Federal Transit Administration (FTA) to "submit documentation pertaining to existing land use, transit-supportive plans and policies, performance and impacts of policies, and other land use considerations" (FTA,2004) ${ }^{13}$. Requirements for national funds can also facilitate coordination between local authorities, interest groups, the different stakeholders that will be involved in the operation of the project, and the public. In the case of Germany, planning procedures with the involvement of interest groups and the public are part of the requirements to national funds for urban transport projects. The development of an Environmental Impact Assessment and a Cost-Benefit Analysis are part of these requirements.

Extending urban transport funds also to operations and/ or setting frameworks that help local governments increase their funds can help to achieve high quality standards of public transport while maintaining systems affordable

In some countries, the national government assigns funds not only for urban transport infrastructure but also to support operations (basically fuel and power costs). This is the case of Germany, US, France, and the UK. While it is important to make sure that the state's provision of such funds does not undermine the incentives for operators to improve their financial efficiency, this practice can facilitate the alignment of interests between transport authorities and service providers towards the achievement of high quality standards of public transport modes while maintaining systems affordable (GIZ and EMBARQ, 2013). Both conditions foster higher ridership and encourage modal shift from private to public modes. For example, in the UK, the national government allocates funding to bus services that are not commercially viable but that are considered socially desirable (GIZ and EMBARQ, 2013).

National governments can also help establish frameworks that guarantee certain funding sources for urban transport to metropolitan authorities, improving their capacity to implement urban sustainable transport strategies. One example is the French "Versement Transport" (VT), adopted in $1971^{14}$. The VT is a "dedicated transport tax levied on employers and based on payroll mass" (ITF, 2012). The VT has proven to be an important share of the budget of Urban Transport Organisation Authorities, constituting about one-third of regional operation expenditures for the STIF in 2012. In addition, the progressive

13 FTA uses this as input to emit recommendations on all projects applying for New Starts funds. This recommendations are submitted to Congress for the New Starts budget allocation every fiscal year (FTA,2004)

14 The VT is optional for local governments to implement. 
lowering of the threshold above which local authorities can implement this tax scheme has provided significant incentives for municipal governments to group together and form a shared Urban Transport Organisation Authority.

\section{Building national project evaluation frameworks can improve fund allocation towards sustainable transport objectives}

National governments' guidance has also proven useful for building project evaluation frameworks that can improve fund allocation according to sustainable transport objectives. In the UK the Department for Transport (DfT) has established that alternatives analysis should be an integral part of project decision making. The central government stipulates alternatives that have to be considered for public transport and road infrastructure projects. For instance, evaluated alternatives for light rail projects should include bus-based options. Demand management policies and public transport alternatives should also be considered and evaluated in the case of highway projects (Hidalgo et.al, 2012). Countries like the UK, Chile, France, Sweden, Norway and Australia, have also created guidelines to conduct cost-benefit analysis for transport projects such as establishing monetisable benefits and costs that should be included, the prices to use, and the discount rate. In some countries, particular efforts have been made to improve incorporation of climate effects in transport appraisal. This is done by adjusting the discount rate used to calculate carbon value to account for the long-term risks that carbon emissions have on future consumption, and the changes this causes on investment decisions. "The United Kingdom and Norway adjust the discount rate for the risk associated with long-term effects by adopting a declining schedule. The Netherlands, Germany and the United States instead adopt a lower but constant discount rate" (ITF, 2015). 


\section{Conclusion}

More than half of the world's population now lives in urban areas; by 2050, the proportion of the world's population living in urban areas is expected to further increase, reaching 66\% (United Nations, 2014). As private motorised modes account today for $90 \%$ of total surface transport sector $\mathrm{CO}_{2}$ emissions, improving mobility through low carbon transport within urban agglomerations provide great potential to reduce carbon emission. This is especially important for rapidly growing cities in the developing world where projections based on current trends, show that travel with private vehicle and thus the growth of $\mathrm{CO}_{2}$ emission will increase significantly over the next decades. Thus, coherent policies aiming at reduction $\mathrm{CO}_{2}$ emissions are strongly needed.

Population density and the density of demand for mobility are higher in cities, and therefore the provision of low carbon public transport is more feasible than in rural areas. Specific projects that involve mass transit investment and/or improvement of existing bus services, such as Metro bus in Mexico, Transmilenio in Colombia, and TransJakarta in Indonesia have shown to contribute to the reduction of the $\mathrm{CO}_{2}$ intensity of urban mobility by "inducing passengers to switch modes, to switch to larger units within modes, or through improved occupancy rates" (Hook, et al., 2010).

However, providing a less carbon intensive transport system that is well integrated and competitive with higher carbon intensive (private) transport modes has proven to be challenging. Fragmentation between local, regional, and national governments as well as across sectors creates policy contradictions and misalignments that hinder the potential to reduce carbon emissions from urban mobility. Thus, dependency on private transport might be increased not only by a disintegrated not-well-connected transport network resulting from insufficient coordination across local governments, but also through urban expansion (unknowingly) promoted by national frameworks (e.g. via property taxes, favouring ownership and single-family homes) and urban housing policies.

Implementing a well-integrated transport system is challenging but not impossible. In metropolitan areas that have achieved a successful integration of their transport system the coordination is often managed through a more formal coordinating body, responsible not only for public transport but urban transport as whole. This way, coordination across municipal boundaries is facilitated and complementary transport policies incentivising low carbon transport usage are easier identified (see e.g. London, Singapore). A close connection with urban development authorities have further proven to result in a more efficient transport provision (see e.g. Curitiba, Brazil) that not only leads to lower carbon emission but also positively affects urban development.

National level government involvement can support local efforts and help achieve faster, more homogeneous and wide spread development of low carbon urban mobility. Development of national level policy for urban sustainable transport has been useful to develop clearer goals, guidelines and standards, and to prioritize funding for public transport and non-motorised projects. Linking granting of national funds to integral urban planning requirements has also proven to incentivize local coordination across jurisdictions and authorities in charge of complementary policies. National funds have been in some cases key to facilitate alignment of interests between transport authorities and service providers to reduce tensions between high quality and affordable public transport. In many cases, national governments have also offered important guidance for project evaluation and improvement of coordination between investment and low carbon mobility goals. 


\section{Bibliography}

Ahrend, R., C. Gamper and A. Schumann (2014), "The OECD Metropolitan Governance Survey: A quantitative description of governance structures in large urban agglomerations", $O E C D$ Regional Development Working Papers, No. 2014/04, OECD Publishing, Paris, http://dx.doi.org/10.1787/5jz43zldh08p-en.

BID (2013). Guía Práctica Estacionamiento y Políticas de Reducción de Congestión en América Latina. Banco Interamericano de Desarrollo.

Cervero (2011). State Roles in Providing Affordable Mass Transport Services for Low-Income Residents. Discussion Paper No. 2011-17, International Transport Forum.

Cervero, Robert, and Danielle Dai (2014), BRT TOD: Leveraging transit oriented development with bus rapid transit investments. Transport Policy 36 (2014): 127-138.

CEPAL (2009). Políticas de movilidad urbana e infraestructura urbana de transport, United Nations Publishing.

Demery, L.W. (2004). Bus Rapid Transit in Curitiba, Brazil - An Information Summary publictransit.us Special Report No. 1

FTA (2004), http://www.fta.dot.gov/documents/FTA_LU_Contractor_Guidelines_FY04_complete1.pdf, accessed November 2014

GART (2014), http://www.gart.org, accessed November 2014

GIZ and EMBARQ (2013). Financing Sustainable Urban Transport - International Review of National Urban Transport Policies and Programmes.

Government of India (2011). Jawaharlal Nehru National Urban Renewal Mission. http://jnnurm.nic.in/wp-content/uploads/2011/01/PMSpeechOverviewE.pdf, accessed November $\underline{2014}$

Hidalgo (2010). Modernizing Public Transportation: Lessons learned from major bus improvements in Latin America and Asia. World Resources Institute.

Hidalgo et al (2012), National Investment in Urban Transport: Towards People's Cities Through Land Use and Transport Integration. EMBARQ India

Hook et al (2010), Carbon Dioxide Reduction Benefits of Bus Rapid Transit Systems: Learning from Bogotá, Colombia; Mexico City, Mexico; and Jakarta, Indonesia. Journal of the Transportation Research Boards No. 219, Transportation Research Board of the National Academies. 
ITDP (2014). Invertir para Movernos: Diagnóstico de Inversiones en Movilidad en las Zonas Metropolitanas de México 2011-2013.

ITDP (2013), https://go.itdp.org/display/ADBdemo/Curitiba+BRT, accessed November 2014

ITF (2015), ITF Transport Outlook 2015, OECD Publishing doi: http://dx.doi.org/10.1787/9789282107782-en

ITF (2013), Funding Urban Public Transport. Case Study Compendium. International Transport Forum.

Lindau, Luis Antonio, Dario Hidalgo, and Daniela Facchini (2010) "Curitiba, the cradle of bus rapid transit." Built Environment 36.3: 274-282.

Kawaguchi, et al. (2013) Cross-Sector Transportation Authority for Jakarta Metropolitan Area, Proceedings of the Eastern Asia Society for Transportation Studies, Vol.9

LTA (2014) Annual Report 2013/2014, www.lta.gov.sg/content/dam/ltaweb/corp/PublicationsResearch/files/AnnualReports/1314/LTA\%2 0AR\%202014\%20web.pdf, accessed November 2014

LTA (2013) Master Plan 2013, www.lta.gov.sg/content/dam/ltaweb/corp/PublicationsResearch/files/ReportNewsletter/LTMP2013 Report.pdf, accessed November 2014

Metropolitan Planning Council (2013), Databook: The Public Transportation Network in Northeastern Illinois, Metropolitan Planning Council, Chicago

Merk, O. (2014), "Metropolitan Governance of Transport and Land Use in Chicago", OECD Regional Development Working Papers, 2014/08, OECD Publishing. dx.doi.org/10.1787/5jxzjs6lp65k-en

Nowak, W., Savage, I. (2013), The cross elasticity between gasoline prices and transit use: Evidence from Chicago, Transport Policy, Vol. 29, pp. 38-45

OECD (2015a), Governing the City, OECD Publishing, Paris. doi: http://dx.doi.org/10.1787/9789264226500-en

OECD (2015b), OECD Urban Policy Reviews: Mexico 2015: Transforming Urban Policy and Housing Finance, OECD Publishing, Paris. doi: http://dx.doi.org/10.1787/9789264227293-en

OECD (2014a), OECD Regional Outlook 2014 - Regions and cities: Where policies and people meet, OECD Publishing. doi: 10.1787/9789264201415-en.

OECD (2013a), Vers une croissance plus inclusive de la métropole Aix-Marseille: Une perspective internationale, OECD Publishing.

OECD (2013b), OECD Territorial Reviews: Puebla-Tlaxcala, Mexico 2013, OECD Publishing. Doi: 10.1787/9789264203464-en.

OECD (2013c), OECD Urban Policy Reviews: Chile 2013, OECD Publishing. Doi: 10.1787/9789264191808-en. 
OECD (2013d), Green Growth in Cities, OECD Green Growth Studies, OECD Publishing. DOI: $\underline{10.1787 / 9789264195325-\mathrm{en}}$

OECD (2013e), Investing Together: Working Effectively across Levels of Government, OECD Publishing. DOI: $\underline{10.1787 / 9789264197022-e n}$

Oregan Metro (2014),Error! Hyperlink reference not valid., accessed November 2014

RMV (2014), Struktur des RMV, www.rmv.de/de/Verschiedenes/Informationen_zum_RMV/Der_RMV/Wir_ueber_uns/Struktur_de s_RMVI, accessed November 2014

SEDATU (2014). Estrategia de Movilidad Urbana Sustentable. Secretaría de Desarrollo Agrario, Territorial y Urbano. Working paper.

STIF (2012). Enquête globale transport. http://www.iauidf.fr/fileadmin/Etudes/etude_954/Enquete_globale_transport_HD.pdf

TomTomTraffic Index 2014, http://www.tomtom.com/lib/doc/pdf/2014-0514\%20TomTomTrafficIndex2013annualEur-mi.pdf, accessed November 2014

Transport for London (TfL) (2014), Standing Orders from 1 October 2014, www.tfl.gov.uk/cdn/static/cms/documents/tfl-standing-orders.pdf, accessed November 2014

Transport for London (tfL) (2013), Health, Safety and Environment report 2012/13, www.tfl.gov.uk/cdn/static/cms/documents/health-safety-and-environment-report-2012-13final.pdf, accessed November 2014

United Nations (2014), World Urbanisation Prospects: The 2012 Revision http://esa.un.org/unpd/wup/, accessed November 2014

URBS 2014, http://www.urbs.curitiba.pr.gov.br/, accessed November 2014 
